\title{
Reduction of chromate and carotene-synthesizing activity of selenite-resistant mutants of the yeast Xanthophyllomyces dendrorhous (Phaffia rhodozyma)
}

\author{
H. I. Nechay ${ }^{1,2}$, H. P. Ksheminska ${ }^{1}$, H. V. Kolisnyk ${ }^{2}$, M. Grzadka ${ }^{3}$, M. V. Gonchar ${ }^{1,3}$
}

\author{
${ }^{1}$ Institute of Cell Biology NAS of Ukraine \\ 14/16, Drahomanov St., Lviv, Ukraine, 79005 \\ ${ }^{2}$ Institute of animal biology UAAS \\ 38, Vasylya Stusa Str., Lviv, Ukraine 79034 \\ ${ }^{3}$ Branch Campus of the Faculty of Biotechnology, University of Rzeszow \\ 26, Sokolowska Str., 36-100 Kolbuszowa, Poland
}

nechai_g@ukr.net

\begin{abstract}
Aim. The yeast $P$. rhodozyma is a perspective microbial producer of carotenoid pigment astaxanthin with a high antioxidant power. The aim of the work was to study the ability of the selenite-resistant strains of this yeast to reduce chrome(VI) compounds, as well as to analyze the relations between synthesis of carotenoids, resistance to selenite and chromate-reducing activity of P. rhodozyma. Methods. The yeast cells were grown at standard conditions for this species. The residual chromate content in cultural liquid was determined colorimetrically using diphenylcarbazide. The carotenoid content was determined after extraction of the pigments from the previously permeabilized cells by organic solvents. Results. The selected selenite-resistant mutants of the yeast $P$. rhodozyma revealed the different combinations of the phenotypes related with tolerance/sensitivity to chromate and selenite, as well as ability to reduce chromate. Conclusions. The obtained results give reasons for suggesting that pathways of detoxification of chromate and selenite by the yeast $P$. rhodozyma are different, although run through a common reductive type. The isolated mutant strains would be served as the useful models to study relations between homeostasis of Se and Cr oxyanions and biosynthesis of carotenes.
\end{abstract}

Keywords: chromate, reduction, selenite, carotenes, Xantho- phyllomyces dendrorhous (Phaffia rhodozyma).

Introduction. Due to wide industrial application and distinguishing oxidizing abilities, chromium(VI) compounds are considered to be dangerous environment pollutants. Chromates $\left(\mathrm{CrO}_{4}^{2-}\right)$ and

(C) Institute of Molecular Biology and Genetics NAS of Ukraine, 2009 bichromates $\left(\mathrm{Cr}_{2} \mathrm{O}_{7}{ }^{2-}\right)$ are water soluble and capable of penetrating biological membranes. In microorganisms, in the yeasts in particular, this process is mediated by sulphate transporters, the products of SUL1 and SUL2 genes [1], which is the basis for selection of mutants 
impaired in sulphate transportation related to chromate resistance [2]. After penetrating a cell, $\mathrm{Cr}(\mathrm{VI})$ compounds react with intercellular proteins, nucleic acids, and other cell components, causing mutagenic and carcinogenic effects $[3,4]$.

Living cells are capable of intracellular reduction of $\mathrm{Cr}(\mathrm{VI})$ to $\mathrm{Cr}(\mathrm{III})$. This process is related to detoxification, as it was shown that $\mathrm{Cr}(\mathrm{III})$ compounds are 100 -fold less toxic for bacteria and fungi compared to $\mathrm{Cr}(\mathrm{VI})$ compounds. Intracellular reduction may take place via non-enzymatic and enzymatic pathways. Ascorbic acid, glutathione, and cysteine are efficient reducers of $\mathrm{Cr}(\mathrm{VI})$ to $\mathrm{Cr}(\mathrm{III})$ at physiological conditions. The mechanisms of enzymatic reduction of chromates are well studied in bacteria and may function both at aerobic and anaerobic conditions. For instance, $\mathrm{Cr}(\mathrm{VI})$-resistant strains of Enterobacter cloacae reduce chromates in anaerobic conditions, using $\mathrm{Cr}(\mathrm{VI})$ as electron acceptors. In bacteria, causing aerobic chromate reduction (Pseudomonas, Aeromonas, etc.), this process is catalyzed by NADH-and NADP $(\mathrm{H})$-dependent reductases [5, 6].

As for eukaryotic microorganisms, yeasts in particular, it is yet to be determined which reduction system either enzymatic/non-enzymatic one or intra-/extracellular one - plays a decisive role in chromate-detoxification processes. Besides, there are no data on the ability of biotechnologycally promising yeast Xanthophyllomyces dendrorhous (Phaffia rhodozyma) to detoxicate and remediate chromates. Astaxanthin, the main carotenoid pigment, synthesized by the mentioned yeast, is notable for its powerful antioxidant activity that is 500 times higher than that of $\alpha$-tocopherol, which is the highest among all the known carotenoids [7-9]. Due to this fact the yeast $X$. dendrorhous is considered to be a promising source in production of pharmacological preparations for cancer prevention, improvement of immune response, and protection from the activity of free radicals.

At the same time, considerable differences in redox-potentials of astaxanthin $\left(E^{0}=0.75 \mathrm{~V}\right)$ and chromate $\left(E^{0}=1.33 \mathrm{~V}\right)[10,11]$ allow the assumption on increased activity of carotene-synthesizing yeast $X$. dendrorhous related to chromate reduction. In order to increase reduction detoxification potential of astaxanthin-synthesizing yeast we performed a selec- tion of mutants of the yeast $P$. rhodozyma, resistant to selenite [12].

The aim of this work was the investigation on reduction features of selenite-resistant strains of carotene-synthesizing yeast $P$. rhodozyma related to chromium(VI) compounds and the analysis of the interrelation between the level of carotenoid synthesis, resistance to selenite, and ability of chromium reduction.

Materials and Methods. The objects of our investigation were wild-type strains of $X$. dendrorhous (P. rhodozyma) NRRL Y-10921 from the collection of microorganisms of the Institute of Cell Biology, NAS of Ukraine, and mutants of $P$. rhodozyma, obtained by us, which demonstrated resistance to sodium selenite (sit strains).

The yeast was grown on rotor shaker at $250 \mathrm{rpm}, t=$ $22^{\circ} \mathrm{C}$, in $100 \mathrm{ml}$ Erlenmeyer flasks, filled with $10 \mathrm{ml}$ of the medium with the following composition $(\mathrm{g} / \mathrm{l})$ : $\mathrm{KH}_{2} \mathrm{PO}_{4}-1 ; \mathrm{MgSO}_{4} \cdot 7 \mathrm{H}_{2} \mathrm{O}-0.5 ;\left(\mathrm{NH}_{4}\right)_{2} \mathrm{SO}_{4}-2 ; \mathrm{CaCl}_{2} \mathrm{x}$ $2 \mathrm{H}_{2} \mathrm{O}-0.1$; yeast extract -2 ; sucrose -20 ; biotin $-1 \cdot 10^{-6}$.

The selection of spontaneous sit-mutants of $X$. dendrorhous was performed collecting the yeast colonies, grown on agarose medium in the presence of 7.5 $\mathrm{mM} \mathrm{Na}_{2} \mathrm{SeO}_{3}$.

The exponential growth cells (the first 24 hours) were used in experiments. A sterile solution of potassium chromate was added to cells' suspension with the concentration of $0.5 \mathrm{mg} / \mathrm{ml}$ with subsequent incubation at $t=22^{\circ} \mathrm{C}$ and aeration. The biomass was determined using optic density of cells' suspension at the wavelength of $540 \mathrm{~nm}$ with subsequent calculation into absolute dry biomass of cells in accordance to the calibration curve.

The resistance of mutant $P$. rhodozyma strains to sodium selenite was analyzed by applying cells' suspension $(0.2 \mathrm{mg} / \mathrm{ml})$ on agarose medium with the range of selenite concentration from 1 to $30 \mathrm{mM}$ with the subsequent study of growth kinetics in 2 days growing at $t=22^{\circ} \mathrm{C}$.

The content of carotenoids was determined after permeabilization of yeast cells by dimethyl sulphoxide with subsequent extraction of carotenoids into hexane-ethyl acetate mixtures [13]. During the incubation of yeast cells with chromate, the concentration of residual chromate in the cultural liquid was determined by 


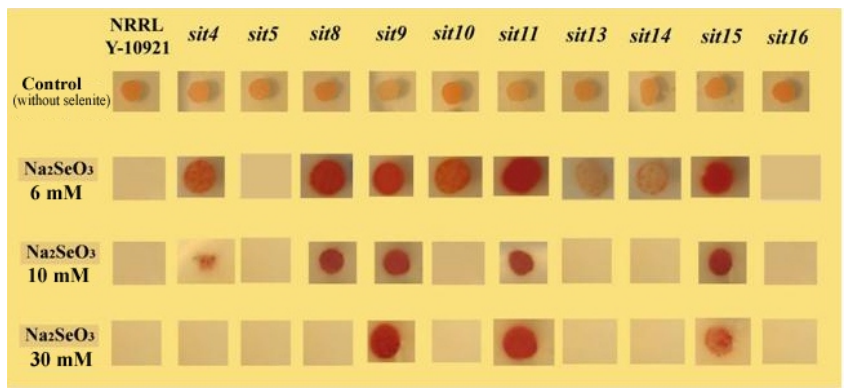

Fig. 1 Test for resistance of the cells of wild-type strain of $P$. rhodozyma NRRL Y-10921 and mutant sit-strains to sodium selenite

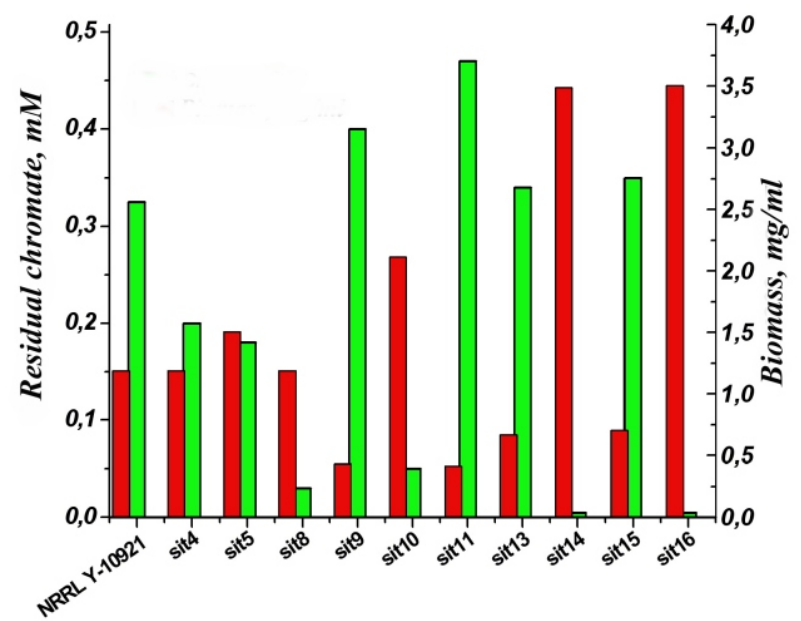

Fig. 2 Growth and residual content of chromate in extracellular liquid of the yeast $P$. rhodozyma on the $4^{\text {th }}$ day of incubation of the cells with $0.9 \mathrm{mM}$ chromate: redcolumns - biomass; green columns $-\mathrm{Cr}(\mathrm{VI})$.

means of colorimetric diphenylcarbaside method [6]. All the experiments were repeated three times.

Results and Discussion. There are numerous literature data on the ability of sulphate-reducing cells of microorganisms to reduce $\mathrm{Cr}(\mathrm{VI})$ [14]. As selenate and sulphate are of the same reduction system, characterized by mutual competitiveness $[15,16]$, one may extend this analogy and assume that compounds of chromium and selenium may also have common enzymatic mechanisms of reduction. Fig.1 demonstrates the results of testing initial and derivative sit-mutants of $X$. dendrorhous, selected via positive selection in the medium with $7.5 \mathrm{mM}$ of potassium selenite, concerning their resistance to selenite.

Isolated mutant strains of $P$. rhodozyma showed different degrees of resistance to this toxic factor. Wild-type strain of $P$. rhodozyma NRRL Y-10921 did not grow at $6 \mathrm{mM} \mathrm{Na}_{2} \mathrm{SeO}_{3}$, while six sit-strains out of ten were actively growing at this concentration of sodium selenite. Even in case of five-fold increase in $\mathrm{Na}_{2} \mathrm{SeO}_{3}$ concentration in agarose medium $(30 \mathrm{mM})$, there still were three strains - sit9, sit11, and sit15, the growth of which was steady; sit 9 and sit 11 showed the highest resistance to selenite.

The ability of selenite-resistant strains of carotene-synthesizing yeast $X$. dendrorhous to reduce chromium(VI) compounds was studied via monitoring of growth and content of residual chromate in the cultural liquid for 6 days of yeast incubation (initial concentration $-0.5 \mathrm{mg} / \mathrm{ml}$ ) with $0.9 \mathrm{mM}$ of chromate. Fig. 2 demonstrates the results of the experiment on the $4^{\text {th }}$ day of yeast incubation.

It was revealed that isolated mutants with different level of resistance to selenite demonstrate different tolerance to chromate, both in the ability to grow in the presence of chromate and in the level of its reduction. For instance, two selenite resistant strains sit14 and sit 16 reduced all the chromate and had the highest biomass increase -5.40 and $5.36 \mathrm{mg} / \mathrm{ml}$, respectively. The strains with remaining 3-22\% chromate in their culture (sit4, sit5, sit8) were characterized by more intensive growth compared to strains, reducing about a half of added chromate ( sit9, sit11, sit13, sit15). The correlation analysis of growth activity data and values of residual content of chromate for tested strains revealed clear negative correlation between these parameters $(R=$ $-0.825)$. Thus, the strains, reducing chromate the most efficiently (lower level of residual Cr(VI) in the cultural liquid) usually grow better in the presence of $\mathrm{Cr}(\mathrm{VI})$.

The study on carotene-synthesizing activity of investigated $P$. rhodozyma strains revealed inhibition of this process in the presence of high concentrations of chromate in the incubation mixture. The cells did not have any colour until chromate concentration in the medium decreased to app. $0.2 \mathrm{mM}$, which caused active growth of yeast and synthesis of carotenoids. Therefore, chromate inhibits the process of carotenoid synthesis along with growth inhibition.

Fig. 3 demonstrates the growth kinetics and process of chromate reduction for some sit-mutants of the yeast. Strains sit 15 and sit16 showed the highest activity in their growth and chromate reduction, besides, chromate disappeared from the cultural liquid sooner - in 4 days of incubation, while concentration of chromate on the 

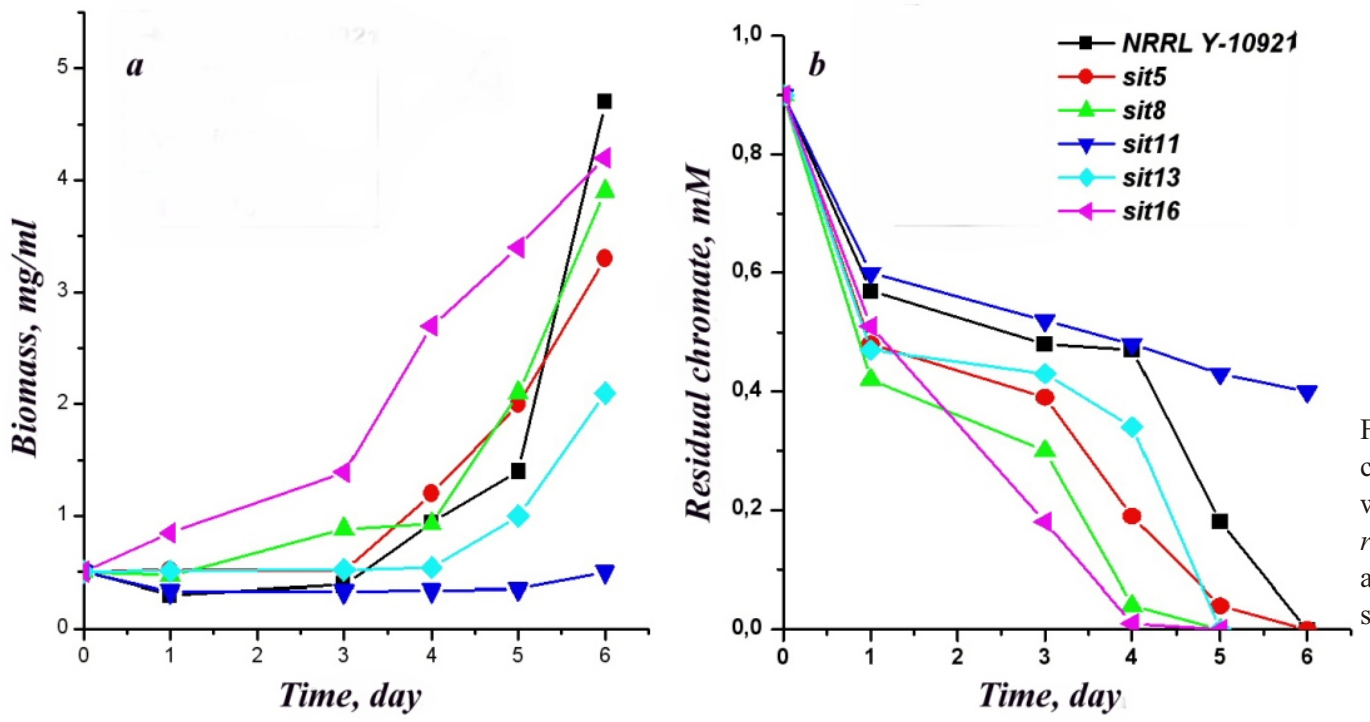

Fig. 3 Growth kinetics $(a)$ and chromium reduction $(b)$ for wild-type strain of the yeast $P$. rhodozyma NRRL Y-10921 and mutants, resistant to selenite. $6^{\text {th }}$ days of incubation for strains sit9 and sit11 was decreased only by half and amounted to $0.4-0.5 \mathrm{mM}$ at the end of experiment. Strains sit9 and sit11 were also notable for the slowest growth rate. Growth intensification of the rest of mutants coincided with chromate decrease in the cultural liquid; strains sit8, sit13 and sit5, wild-type strain reduced all the chromate on the $5^{\text {th }}$ and $6^{\text {th }}$ days of experiment, respectively.

Therefore, the analysis of ability to reduce chromate of mutant strains with the highest resistance to selenite (sit9, sit11, sit15) showed that chromate in the concentration of $0.9 \mathrm{mM}$ inhibits their growth considerably; at the same time they reduce it much worse compared to strains sit14 and sit16, resistance to selenite of which is less expressed. It may testify to a difference in reduction pathways of these two anions. Our previous works on the model of flavinogenous yeast Pichia guilliermondii [17] demonstrated that mutants, resistant to selenite, are characterized by the ability of accumulating elementary selenium $\left(\mathrm{Se}^{0}\right)$ in cells, while reduction detoxification of chromate in this yeast results in accumulation of $\mathrm{Cr}$ (III) biocomplexes in the cultural liquid $[6,18]$.

Thus, different nature of end products of reducing toxic oxianions of chromium and selenium and differences in their localization may result in ambiguous interrelation between resistance phenotypes to selenite and chromate. It is also possible that increased ability to reductive detoxification of selenite in selenite-resistant strains of $X$. dendrorhous results in the increase in the pool of a very toxic radical $\mathrm{Cr}(\mathrm{V})$ - the intermediate of $\mathrm{Cr}(\mathrm{VI})$ reduction. We intend to verify this hypothesis via monitoring of $\mathrm{Cr}(\mathrm{V})$ generation in the cultures of sit-mutants using EPR-spectroscopy, as we have done before for chromate-resistant strains of flavinogenous yeast $P$. guilliermondii $[20,21]$.

We cultivated yeast cells for 4 days and on obtaining the maximal level of carotenoid synthesis [19] we determined total content of carotenoids and biomass increase for wild-type strains and mutants (Fig.4).

The majority of selenite-resistant strains synthesized less carotenoids than the initial strain, which produced $327 \mu \mathrm{g} / \mathrm{g}$ of dry biomass, and the coefficient of decrease in carotene-synthesizing activity for mutants was fluctuating from 1.1 to 2.5 . Only strain sit 16 produced carotenoids on the level, similar to that of wild-type strain. The analysis of interrelation between resistance to sodium selenite and the content of carotenoids, produced by the tested strains, revealed that mutants sit9, sit11, sit15 are the most resistant to sodium selenite and they synthesize approximately twice less carotenoids compared to the wild-type strain. This fact may testify to the absence of direct correlation between the level of carotenogenesis and ability to selenite detoxification.

We have analyzed the resistance of obtained sit-mutants of the yeast $P$. rhodozyma to selenite (Fig.1), compared obtained results to the data on their 
Phenotype parameters of resistance of P. rhodozyma sit-mutants to selenite and chromate

\begin{tabular}{|c|c|c|c|}
\hline $\begin{array}{l}\text { Phenotype } \\
\text { group }\end{array}$ & Chromate & Selenite & P. rhodozyma strains \\
\hline I & Resistant & Resistant & sit8, sit 10 \\
\hline II & Resistant & Level of control & sit 14 , sit16 \\
\hline III & Sensitive & Over-resistant & sit9, sit11, sit15 \\
\hline
\end{tabular}

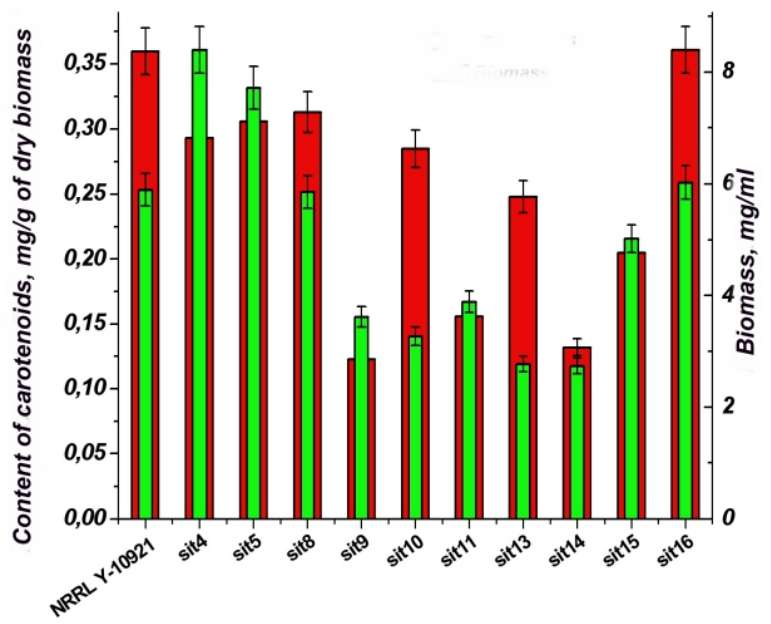

Fig. 4 Growth and synthesis of carotenoids for wild-type strain of $P$. rhodozyma NRRL Y-10921 and mutants, resistant to sodium selenite, in the medium without the addition of the latter: red columns - carotenoids; green columns - biomass

ability to reduce chromate (Fig.2), and divided all the investigated strains into three groups according to phenotype characteristics (Table).

It turned out that there are practically all the combinations of phenotypes related to resistance/sensitivity to chromate and selenite which testifies to the absence of definite dependence between resistance to oxianions of chromium and selenium.

Conclusions. The results obtained allow the assumption that the pathways of chromate and selenite detoxification in the yeast $P$. rhodozyma are different though these processes take place according to a common reductive type. The absence of definite dependence between the resistance to chromate and selenite and the ability of the yeast to synthesize carotenoids testifies to the necessity of searching for biochemical and genetic mechanisms, responsible for these processes. Obtained mutants with different combination of phenotypes of resistance to selenium and chromium oxianions will serve a convenient model in the study on interrelation between homeostasis of the mentioned elements and biosynthesis of carotenoids with a high antioxidant activity.

The authors would like to express their sincere gratitude to the Scientific Research Committee (Poland) for financial support, provided in the framework of Polish-Ukrainian grant "Mutants of non-conventional yeast for efficient bioremediation of chromate and purification of industrial sewage".

\section{Г. І. Нечай, Г. П. Кшемінська, Г. В. Колісник, М. Гжондка, М. В. Гончар}

Редукція хромату та каротиносинтезувальна активність резистентних до селеніту мутантів дріжджів Xanthophyllomyces dendrorhous (Phaffia rhodozyma)

Резюме

Мета. Дріжджі Р. rhodozyma є перспективними біопродуцентами, оскільки синтезують каротиноїдний пігмент астаксантин з високою антиоксидантною активністю. Мета роботи полягала у вивченні здатності резистентних до селеніту штамів редукувати сполуки хрому(VI) $і$ в аналізі взаємозв'язку між рівнем синтезу каротиноїдів, стійкістю до селеніту та редукуючими властивостями щуодо хромату. Методи. Дріжджі вирощували за стандартних для даного виду умов. Вміст залишкового хромату в культуральній рідині визначали колориметрично дифенілкарбазидним методом. Кількість каротиноїдів виявляли екстракиією пігментів органічними розчинниками із попередньо пермеабілізованих клітин. Результати. Виділені селеніт-резистентні мутанти дріжджів P. rhodozута проявили різні комбінації фенотипів за стійкістю/чутливістю до хромату і селеніту та здатністю до редукиії хромату. Висновки. Одержані результати дають підставу припустити, що шляхи детоксикації хромату $і$ селеніту у дріжджів Р. rhodоzута є різними, хоча і здійснюються за однаковим редукиійним типом. Мутантні итами можуть стати зручною моделлю для вивчення взаємозв'язку між гомеостазом оксіаніонів селену і хрому та біосинтезом каротиноїдів.

Ключові слова: хромат, редукиія, селеніт, каротиноїди, Xanthophyllomyces dendrorhous (Phaffia rhodozyma). 
Г. И. Нечай, Г. П. Кшеминская, А. В. Колесник, М. Гжондка, М. В. Гончар

Редукция хромата и каротинсинтезирующая активность резистентных к селениту мутантов дрожжей Xanthophyllomyces dendrorhous (Phaffia rhodozyma)

Резюме

Введение. Дрожжи P. rhodozyma - перспективный биотехнологический продуиент, синтезирующций каротиноидный пигмент астаксантин с высоким антиоксидантным потенциалом. Цель работы состояла в изучении способности резистентных к селениту штаммов редуцировать соединения хрома (VI) и в анализе взаимосвязи между уровнем синтеза каротиноидов, стойкостью к селениту и редуцирующими свойствами по отношению к хромату. Методы. Клетки дрожжей выращивали в стандартних для этого вида условиях. Остаточное содержание хромата в культуральной жидкости определяли колориметрически, используя дифенилкарбазид. Содержание каротиноидов определяли экстракцией пигментов смесью органических растворителей из предварительно пермеабилизованных клеток. Результаты. Выделенные селенит-резистентные мутанты дрожжей P. rhodozyта проявили различные комбинации фенотипов стойкости/чувствительности к хромату и селениту, а также способности к редукиии хромата. Выводы. Полученные результаты дают основание полагать, что пути детоксикации хромата и селенита у дрожжей P. rhodozyта разные, хотя осуществляются по общему редукиионному типу. Мутантне итаммы могут стать удобной моделью для изучения взаимосвязи между гомеостазом оксианионов селена и хрома и биосинтезом каротиноидов.

Ключевые слова: хромат, редукиия, селенит, каротиноиды, Xanthophyllomyces dendrorhous (Phaffia rhodozyma).

\section{REFERENCES}

1. Cherest H., Davidian J., Thomas D., Benes V., Ansorge W., Surdin-Kerjan $V$. Molecular characterization of two high affinity sulfate transporters in Saccharomyces cerevisiae // Genetics.-1997.-145, N 3.-P. 627-635.

2. Breton A., Surdin-Kerjan V. Sulfate uptake in Saccharomyces cerevisiae: biochemical and genetic study // J. Bacteriol.1977.-132, N 1.-P. 224-232.

3. Camargo F. A. O., Bento F. M., Okeke B. C., Frankenberger $W$. T. Chromate reduction by chromium-resistant bacteria isolated from soils contaminated with dichromate // J. Environ. Qual.-2003.-32, N 4.-P. 1228-1233.

4. Mabrouk M. E. M. Statistical optimization of medium components for chromate reduction by halophilic Streptomyces sp. MS-2 // Afr. J. Microbiol. Res.-2008.-2.-P. 103-109.

5. Baldi F., Vaghan A. M., Olson G. Chromium (VI)-resistant yeast isolated from a sewage treatment plant receiving tannery wastes // Appl. Environ Microbiol.-1990.-56, N 4.P. 913-918.

6. Ksheminska H. P., Honchar T. M., Gayda G. Z., Gonchar M. $V$. Extra-cellular chromate-reducing activity of the yeast cultures // Cent. Eur. J. Biol.-2006.-1, N 1.-P. 137-149.
7. Kaminska M., Solohub L. The carotenoproduced yeast Phaffia rhodozyma // Visnyk of L'viv Univ., Biology Series.2004.-37.-P. 3-12.

8. Higuera-Ciapara I., Felix-Valenzuela L., Goycoolea F. M. Astaxanthin: a review of its chemistry and applications // Crit. Rev. Food. Sci. Nutr.-2006.-46, N 2.-P. 185-196.

9. Verdoes J. C., Sandmann G., Visser H., Diaz M., Mossel M., Ooyen A. Metabolic engineering of the carotenoid biosynthetic pathway in the yeast Xanthophyllomyces dendrorhous (Phaffia rhodozyma) // Appl. Environ Microbiol.-2003.-69, N 7.-P. 3728-3738

10. Han R., Tian Y., Wu Y., Wang P., Ai X., Zhang J., Skibsted L. Mechanism of radical cation formation from the excited states of zeaxanthin and astaxanthin in chloroform // Photochem. Photobiol.-2006.-82, N 2.-P. 538-546.

11. Park D., Park J. M., Yun Y. S. Mechanisms of the removal of hexavalent chromium by biomaterials or biomaterial-based activated carbons // J. Hazard. Mater.-2006.-137, N 2.P. 1254-1257.

12. Nechai H. Isolation spontaneous mutants of carotene-synthesizing yeast Phaffia rhodozyma which are resistant to sodium selenite // Abstr. II Int. Conf. of Young Scientist «Biology: from molecular to biosphere» (19-21 Nov. 2007, Kharkiv).Kharkiv, 2007.-P. 386.

13. Sedmak J. J., Weerasinghe D. K., Jolly S. O. Extraction and quantitation of astaxanthin from Phaffia rhodozyma // Biotech. Tech.-1990.-4, N 2.-P. 107-112.

14. Rahman M. U., Gul S., Ul Haq M. Z. Reduction of chromium(VI) by locally isolated Pseudomonas sp. C-171// Turk. J. Biol.-2007.-31.-P. 161-166.

15. Banszky L., Simonics T., Maraz A. Sulphate metabolism of selenate-resistant mutants Schizosaccharomyces pombe // J. Gen. Appl. Microbiol.-2003.-49.-P. 271-278.

16. Birringer M., Pilawa S., Flohe L. Trends in selenium biochemistry // Nat. Prod. Rep.-2002.-19.-P. 693-718.

17. Chaban L., Pokrovetcka O., Stenchuk M., Gonchar M. Isolation and physiological characterization of selenite-resistant mutants of the yeast Pichia guilliermondii // Visnyk of L'viv Univ., Biology Series.-2004.-34.-P. 92-99.

18. Ksheminska H., Fedorovich D., Honchar T., Ivash M., Gonchar $M$. Yeast tolerance to chromium depends on extracellular chromate reduction and $\mathrm{Cr}$ (III)-chelation // Food Technol. Biotechnol.- 2008.-46, N 4. - P. 420-427.

19. Ni H., Chen Q., Ruan H., Yang Y., Li L.,Wu G., HuW., He G. Studies on optimization of nitrogen sources for astaxanthin production by Phaffia rhodozyma // J. Zhejiang Univ. Sci. B.-2007.-8, N 5.-P. 365-370.

20. Ksheminska H., Honchar T., Usatenko Yu., Gonchar M. Extra-cellular chromate-reducing activity of the yeast cultures // Abstr. II Polish-Ukrain. Weigl Conf. «Microbiology in the XXI century» (24-26 Sept. 2007, Warsaw).-Warsaw, 2007.P. 240.

21. Gayda G., Ksheminska H., Prokopiv T., Ivash M., Nechay G., Usatenko Y., Gonchar. M. Extra-cellular reduction in chromate detoxification by daker's and non-conventional yeasts: Study of the mechanisms of $\mathrm{Cr}$ (III)-biochelates generation and their characterization // Abstr. XII Int. Congr. on Yeasts (11-15 Aug., 2008, Kyiv).-Kyiv, 2008.-P. 197.

UDC 579.222.7

Received 16.01.09 